\title{
The effect of mineral fertilizers on the seasonal dynamics of exchangeable potassium in the orchard soil and the potassium status of sour cherry trees
}

\author{
Tatyana Roeva*',Elena Leonicheva \\ Russian Research Institute of Fruit Crop Breeding (VNIISPK), Zhilina, Orel district, Orel region, \\ Russian Federation
}

\begin{abstract}
The study was conducted to assess the impact of mineral fertilizers applied to the soil on the potassium level in the components of the "soil-plant" system of the sour cherry orchard. The experiment was conducted in the forest-steppe zone of the Central Russian Upland (Orel region) on loamy Haplic Luvisol during 2018-2020. The seasonal dynamics of exchangeable potassiumin the soil, the potassium status and productivity of sour cherry trees cv. 'Turgenevka' on the rootstock V-2180 were studied in the orchard of 2015 planting. Fertilizers in the form of $\left(\mathrm{NH}_{2}\right)_{2} \mathrm{CO}$ and $\mathrm{K}_{2} \mathrm{SO}_{4}$ were applied annually in early spring in doses of $\mathrm{N} 30 \mathrm{~K} 40, \mathrm{~N} 60 \mathrm{~K} 80, \mathrm{~N} 90 \mathrm{~K} 120$ and N120K160. It was found that a significant decrease in the level of potassium in the soil occurred during the period of intensive growth and crop formation, or after heavy precipitation. The use of fertilizers increased the content of exchangeable potassium in the soil (by 1.2-2.2 times), while the features of the potassium dynamics observed in unfertilized plots were preserved. Fertilizers contributed to the annual improvement of the potassium status of the leaves (by 0.05-0.24\% DW). The positive effect of fertilizers on the potassium content in fruits and the productivity of trees was manifested only in a year with prolonged intense precipitation (2020). The potassium content in fruits was 1.12-1.16 times higher than the control when applying $\mathrm{N} 30 \mathrm{~K} 40$, N60K80 and N90K120. A significant increase of tree productivity was found when applying N60K80 and N120K160 (by 54 and $69 \%$, respectively).
\end{abstract}

\section{Introduction}

Over the past 30 years, global fruit production has increased dramatically. The total volume of fruit production (excluding citrus fruits) in 1986 amounted to 387,685,120 tons, and in 2016 - 865,876,405 tons. Similar trends are typical for the group of stone fruit crops, including cherry. In 2016 , the volume of cherry production increased by $17.1 \%$ compared to 1986 and amounted to $1,378,216$ tons. Europe is considered the largest cherry producer.

\footnotetext{
*Corresponding author: roeva@vniispk.ru
} 
The leading cherry producing countries are the Russian Federation, Poland, Turkey, Ukraine and the United States [1].

One of the factors contributing to the sustainable production of cherry fruits is the use of a balanced fertilizer system. Cherry trees uptake significant amounts of mineral elements from the soil, including potassium, which is in second place after nitrogen in terms of absorption [2]. Potassium improves the quality of fruits by enhancing the synthesis and translocation of carbohydrates in plants [3]. The use of optimal doses of potash fertilizers increases the productivity of sourcherry trees [4], contributes to an increase in the size and hardness of fruits [5]. There is evidence of a significant correlation of the potassium status of cherry leaves with the yield of the next year [6]. On the other hand, extremely high doses of potash fertilizers can lead to adeterioration in the quality of cherry fruits $[5,7]$, as well as reduce the concentration of $\mathrm{Ca}, \mathrm{Mg}$ and $\mathrm{Mn}$ in plants [8].

The exchange forms of soil potassium are the main reserve for plant nutrition. A significant decrease in the exchangeable potassium in the soil and the yield of fruit trees can occur after 6-8 years of their cultivation without fertilization $[9,10]$. Thus, the potassium reserves in the orchard soil are gradually depleted and need to be replenished.

Stone fruit trees, including cherry, have a variable need for potassium during the growing season. Reserves of exchange compounds are the main source for stabilizing the potassium level in the soil solution when plants uptake the element [11]. The study of the dynamics of soil potassium in combination with the determination of the potassium status of cherry trees can be useful for improving the diagnosis of potash nutrition and improving the effectiveness of potassium fertilizers. At present time, information about the features of the potassium regime of soils under fruit crops is reflected only in individual publications [12], and they are not available for cherry. The purpose of the research is to study the influence of potassium fertilizers on the seasonal dynamics of potassium exchange forms in the orchard soil, the potassium status and productivity of cherry trees in the soil and climatic conditions of the Central Russian Upland.

\section{Materials and methods}

The experiment was conducted in 2018-2020 in the cherry orchard of 2015 planting, located in the orchard massive of the Russian Research Institute of Fruit Crop Breeding (Orel region, Russia $53^{\circ} 00$ '09.5"N, $36^{\circ} 04^{\prime} 19.1^{\prime \prime} \mathrm{E}$ ). The layout of the trees is $5 \times 3 \mathrm{~m}$. To conduct the research, the sour cherry trees cv. 'Turgenevka' was selected on the rootstock V-2-180. The soil of the experimental site is classified as loamy Haplic Luvisol, underlain by dolomitic limestones.

The soil has the following agrochemical parameters in a layer of $0 . .20 \mathrm{~cm}: \mathrm{pH}_{\mathrm{KCl}}=5.8$, the content of organic matter $-2.8 \%$, the content of alkaline hydrolyzable nitrogen - 108 $\mathrm{mg} / \mathrm{kg}$, mobile phosphorus - $383 \mathrm{mg} / \mathrm{kg}$, exchangeable potassium $-120 \mathrm{mg} / \mathrm{kg}$. The content of calcium and magnesium exchange compounds in the soil is high: 2.99 and $0.53 \mathrm{~g} / \mathrm{kg}$, respectively. The system of soil maintenance in the rows of trees is herbicide treatment, while plowing was carried out in the spacing.

The field experiment on the study of the effectiveness of mineral fertilizers was started in 2017. Experiment treatments: 1. Control (without fertilizers); 2. N30K40; 3. N60K80; 4. N90K120. 5. N120K160. Nitrogen and potassium fertilizers in granular form $\left(\mathrm{NH}_{2}\right)_{2} \mathrm{CO}$ and $\mathrm{K}_{2} \mathrm{SO}_{4}$ were applied annually in early spring to a depth of $10-15 \mathrm{~cm}$. The experiment is carried out in a three-fold repetition with a randomized arrangement of plots, there are 4 trees on each accounting plot.

Soil samples were taken five times during the growing season: in May, June, July, August and September in the sub-crown zone of trees at a distance of 1.0...1.2 $\mathrm{m}$ from the 
stem from a depth of $0 \ldots 20 \mathrm{~cm}$. In these samples, the content of exchange potassium compounds was determined by extraction of $0.2 \mathrm{M} \mathrm{HCl}$ at the soil:solution ration - 1:5 [13].

Leaf samples were taken in July (65-75 days after flowering) from the middle part of the annual shoots, fruit samples were taken in the ripeness stage. The plant samples were ashed in a muffle furnace at a temperature of $450^{\circ} \mathrm{C}$, the ash was dissolved in $20 \% \mathrm{HCl}$ [13]. The determination of potassium in the ash solution and in extracts from the soil was carried out using a Sherwood 410 flame photometer.

Yield accounting was carried out by the weight method, considering the weight of fruits from each accounting tree.

For statistical data processing, a two-factor variance analysis was used with an assessment of the significance of differences based on the Fisher criterion and the LSD at a significance level of $\mathrm{P}=0.05$ [14]. The confidence interval was calculated using the standard deviation.

\section{Results and discussion}

The level of potassium in the components of the "soil - plant" system of the experimental orchard depended on weather conditions, the uptake of the element by plants and the amount of fertilizers used.

The temperature regime during the three studied periods was close to the average long-term indicators, in some months the temperature exceeded the average level by $0.9-3.5{ }^{\circ} \mathrm{C}$. The exception was the cold May of 2020 (Table 1). The total amount of precipitation and the uniformity of their fall significantly differed in different years. In the summer of 2018, there were two dry periods, as well as a period of extreme precipitation from July 13 to 25 . In 2019, the drought was noted in June, and in the remaining months precipitation fell evenly. In July 2020, an extremely large amount of precipitation also fell.

Table 2. Weather conditions of the growing season.

\begin{tabular}{|c|c|c|c|c|c|c|c|c|}
\hline \multirow{2}{*}{ Month } & \multicolumn{3}{|c|}{$\begin{array}{l}\text { Average monthly } \\
\text { t of the air, }{ }^{0} \mathrm{C}\end{array}$} & \multirow{2}{*}{$\begin{array}{c}40 \text {-year } \\
\text { average } \\
\text { values, }{ }^{0} \mathrm{C}\end{array}$} & \multicolumn{3}{|c|}{ Precipitation amount, $\mathrm{mm}$} & \multirow{2}{*}{$\begin{array}{c}40-y e a r \\
\text { average values, } \\
\mathrm{mm}\end{array}$} \\
\hline & 2018 & 2019 & 2020 & & 2018 & 2019 & 2020 & \\
\hline May & 16.4 & 15.6 & 11.3 & 13.0 & 31.4 & 85.0 & 59.1 & 36.4 \\
\hline June & 17.0 & 20.5 & 19.9 & 16.9 & 18.2 & 20.7 & 46.4 & 65.1 \\
\hline July & 19.9 & 17.4 & 19.6 & 18.5 & 119.9 & 49.8 & 111.6 & 88.0 \\
\hline August & 18.4 & 17.1 & 18.2 & 17.1 & 11.2 & 54.7 & 26.0 & 65.7 \\
\hline September & 14.9 & 12.5 & 15.2 & 11.7 & 45.5 & 50.2 & 23.5 & 43.2 \\
\hline Average & 17.3 & 16.6 & 16.8 & 15.4 & $\begin{array}{c}\Sigma \\
226.2\end{array}$ & $\begin{array}{c}\Sigma \\
260.4\end{array}$ & $\sum_{266.6}$ & $\begin{array}{c}\Sigma \\
298.4\end{array}$ \\
\hline
\end{tabular}

The maximum demand of sour cherry trees for potassium falls on the most important stages of fruit growth and ripening (from mid-May to mid-July). The content of potassium in fruits increases linearly until they mature [15]. The research was carried out in a cherry orchard that is entering fruiting. In 2018, the trees gave the first commercial harvest. A significant increase in tree productivity was established only in 2020 , in the 4 th year after planting trees, with the fertilization of N60K 80 and N120K160 by 54 and 69\%, respectively (Figure $1)$. 




Fig. 1. Productivity of sour cherry trees cv. 'Turgenevka'.

The content of potassium exchange forms in the soil is an indicator traditionally used to assess the availability of agricultural crops with this element. The content of exchangeable potassium in the soil of unfertilized plots during 3 study periods was in the range of 118.6...187.7 (Table 2). According to the gradation for fruit trees [16], these values correspond to the medium range of potassium concentrations in the soil $(100-200 \mathrm{mg} / \mathrm{kg})$.

Due to the peculiarities of weather conditions and the different fruit load of trees, the dynamics of exchangeable potassium content in the root zone was not the same in different years (Table 2).

Table 2.Seasonal changes of exchangeable potassium content $(\mathrm{mg} / \mathrm{kg})$ in the soil layer $0-20 \mathrm{~cm}, 2018-2020$.

\begin{tabular}{|c|c|c|c|c|c|c|}
\hline \multirow{2}{*}{$\begin{array}{l}\text { Samplin } \\
\text { gperiod }\end{array}$} & \multicolumn{5}{|c|}{ Treatments } & \multirow{2}{*}{ Average } \\
\hline & Control & $\mathrm{N} 30 \mathrm{~K} 40$ & N60K80 & N90K120 & N120K160 & \\
\hline \multicolumn{7}{|c|}{2018} \\
\hline May & $123.6 \pm 2.6$ & $175.9 \pm 13.4$ & $228.7 \pm 62.6$ & $270.0 \pm 61.3^{*}$ & $180.6 \pm 18.2$ & $195.8 \pm 27.6$ \\
\hline June & $171.0 \pm 7.3$ & $143.6 \pm 2.8$ & $232.8 \pm 19.2$ & $281.9 \pm 130.4 *$ & $212.0 \pm 6.4$ & $208.3 \pm 31.9$ \\
\hline July & $182.3 \pm 13.1$ & $181.8 \pm 54.3$ & $232.5 \pm 12.2$ & $303.6 \pm 100.3^{*}$ & $227.1 \pm 17.5$ & $225.5 \pm 28.8$ \\
\hline August & $125.8 \pm 4.0$ & $129.1 \pm 4.9$ & $191.2 \pm 11.6$ & $236.2 \pm 34.6^{*}$ & $162.3 \pm 14.9$ & $168.9 \pm 20.1$ \\
\hline $\begin{array}{l}\text { Septem- } \\
\text { ber }\end{array}$ & $142.0 \pm 19.9$ & $149.1 \pm 16.7$ & $211.3 \pm 22.04$ & $210.4 \pm 29.0$ & $202.0 \pm 58.8$ & $182.9 \pm 19.1$ \\
\hline Average & $148.9 \pm 11.6$ & $155.9 \pm 13.7$ & $219.3 \pm 14.6^{*}$ & $260.4 \pm 35.5^{*}$ & $196.8 \pm 15.6^{*}$ & \\
\hline $\mathrm{LSD}_{05}$ & \multicolumn{5}{|c|}{$\begin{array}{c}\text { Treatments }=43.7 \\
\text { Sampling period } \times \text { treatments }=106.7\end{array}$} & $\begin{array}{c}\text { Sampling } \\
\text { period } \\
43.7\end{array}$ \\
\hline \multicolumn{7}{|c|}{2019} \\
\hline May & $182.8 \pm 6.20$ & $205.1 \pm 26.7$ & $243.5 \pm 36.7$ & $244.0 \pm 58.7$ & $205.5 \pm 34.0$ & $216.2 \pm 18.2$ \\
\hline June & $136.5 \pm 38.5$ & $138.8 \pm 2.6$ & $185.3 \pm 29.9$ & $212.1 \pm 32.7$ & $151.5 \pm 36.6$ & $164.8 \pm 18.0$ \\
\hline July & $118.6 \pm 22.3$ & $172.0 \pm 12.2$ & $198.9 \pm 53.9$ & $182.4 \pm 8.8$ & $175.8 \pm 10.8$ & $169.5 \pm 16.3$ \\
\hline August & $183.6 \pm 22.6$ & $207.0 \pm 37.7$ & $214.9 \pm 59.8$ & $230.6 \pm 55.8$ & $248.5 \pm 60.7$ & $216.9 \pm 22.0$ \\
\hline $\begin{array}{l}\text { Septem- } \\
\text { ber }\end{array}$ & $171.2 \pm 21.2$ & $234.5 \pm 30.3$ & $222.5 \pm 68.3$ & $222.9 \pm 16.5$ & $207.3 \pm 4.6$ & $211.7 \pm 17.2$ \\
\hline Average & $158.5 \pm 15.3$ & $191.5 \pm 17.9$ & $212.7 \pm 22.4^{*}$ & $218.4 \pm 18.5^{*}$ & $198.3 \pm 20.2^{*}$ & \\
\hline $\mathrm{LSD}_{05}$ & \multicolumn{5}{|c|}{$\begin{array}{c}\text { Treatments }=39.6 \\
\text { Sampling period } \times \text { treatments }=88.6\end{array}$} & $\begin{array}{c}\text { Sampling } \\
\text { period } \\
39.6 \\
\end{array}$ \\
\hline
\end{tabular}




\begin{tabular}{|l|c|c|c|c|c|c|}
\hline May & $172.0 \pm 6.3$ & $218.8 \pm 3.8$ & $236.0 \pm 33.0$ & $254.8 \pm 52.4^{*}$ & $232.6 \pm 13.8$ & $222.8 \pm 19.4$ \\
\hline June & $142.0 \pm 5.6$ & $229.1 \pm 49.8$ & $193.8 \pm 39.1$ & $270.2 \pm 65.6^{*}$ & $208.8 \pm 22.9$ & $208.8 \pm 23.3$ \\
\hline July & $187.7 \pm 35.1$ & $212.0 \pm 44.0$ & $256.3 \pm 31.4$ & $250.6 \pm 2.4$ & $253.6 \pm 9.7$ & $231.7 \pm 16.8$ \\
\hline August & $153.2 \pm 7.1$ & $177.7 \pm 26.5$ & $179.7 \pm 54.5$ & $236.6 \pm 9.8^{*}$ & $193.9 \pm 14.2$ & $188.2 \pm 31.2$ \\
\hline $\begin{array}{l}\text { Septem- } \\
\text { ber }\end{array}$ & $148.1 \pm 16.4$ & $173.7 \pm 23.1$ & $208.4 \pm 42.9$ & $260.3 \pm 55.6^{*}$ & $207.8 \pm 18.1$ & $199.6 \pm 21.4$ \\
\hline Average & $160.6 \pm 11.3$ & $202.3 \pm 17.3$ & $214.8 \pm 21.6^{*}$ & $254.5 \pm 24.0^{*}$ & $219.3 \pm 11.5^{*}$ & \\
\hline \multicolumn{5}{|c|}{$\begin{array}{c}\text { Treatments }=35.0 \\
\text { LSD } 05\end{array}$} & \multicolumn{7}{|c|}{$\begin{array}{c}\text { Sampling } \\
\text { period } \\
35.0\end{array}$} \\
\hline
\end{tabular}

*differences with control are reliable at $5 \%$ significance level

In 2018, the high level of exchangeable potassium in the soil of the control plots was observed in June and July, and in August the content of the element sharply decreased (by 1.5 times). In September, the potassium content increased again, but did not reach the level of the summer months. A similar dynamics of the indicator was observed in the soil of fertilized plots. The high level of soil potassium in May-July 2018 could be associated with a weak uptake of the element by plants due to a prolonged drought and a low yield of young trees. The decrease in the content of the exchange forms of the element in August could occur due to its leaching into the underlying soil layers after heavy July precipitation. The introduction of $80 \mathrm{~kg} / \mathrm{ha}$ of potassium fertilizers and more contributed to a significant increase in the reserves of exchangeable potassium in the upper soil layer.

In 2019, with a twofold increase in the fruit load of trees, the lowest content of potassium in the soil was observed in the months of crop formation and ripening (JuneJuly). With uniform precipitation in the second half of the growing season, the level of exchangeable potassium in August-September 2019 increased to the May values of the indicator in all variants of the experiment. Such a restoration of the concentration of the exchange forms of the element could occur due to the dynamic equilibrium characteristic of the soil between the forms of potassium having different binding force with the soil absorbing complex. Similarly to the previous year, the potassium content in the soil significantly exceeded the control, when the doses of potassium fertilizers were at least 80 $\mathrm{kg} / \mathrm{ha}$.

In 2020, as in 2018, the most significant factor affecting the potassium regime of the soil was weather conditions. After heavy July rains, a significant decrease in potassium levels was observed in August. Studies previously conducted in this field experiment have shown the possibility of potassium leaching into deeper soil layers [17]. In 2020, all doses of potassium fertilizers used in the experiment contributed to a significant increase in the content of exchangeable potassium.

It is known that with regular use of potassium fertilizers, the content of exchangeable potassium gradually increases and subsequently stabilizes at a certain level specific to a particular soil [11]. The rate of accumulation of exchangeable potassium compounds in the orchard soil depended on the doses of fertilizers. A high level of potassium content in the soil (more than $200 \mathrm{mg} / \mathrm{kg}$ ) was achieved already in the second year of application of potassium fertilizers (in 2018) at doses of $80 \mathrm{~kg} / \mathrm{ha}$ and higher. When applying potassium sulfate at a dose of $40 \mathrm{~kg} / \mathrm{ha}$, a similar effect was achieved 2 years later (in 2020).

The potassium content in cherry leaves during the 3 years of the experiment varied in the range of $0.52-1.04 \%$ DW (Table 3 ). The values of the indicator were lower than the range of optimal potassium concentration in the leaves, which is $1.1-1.8 \%$ for fruit-bearing cherry trees [18]. The low potassium status of cherry trees, observed at medium and high levels of potassium in the soil, may be associated with a high content of calcium and magnesium cations in the root zone. It is known that $\mathrm{K}, \mathrm{Ca}$ and $\mathrm{Mg}$ are antagonists in the 
processes of root intake into plants [19]. The number and ratio of the exchange forms of these elements in the soil absorbing complex is an important factor determining their entry into the tissues of fruit trees [20].

Table 3.Leaf and fruit potassium content of sour cherry trees cv. 'Turgenevka', 2018-2020.

\begin{tabular}{|c|c|c|c|c|}
\hline \multirow[t]{2}{*}{ Treatments } & \multicolumn{3}{|c|}{ Year } & \multirow[t]{2}{*}{ Average } \\
\hline & 2018 & 2019 & 2020 & \\
\hline \multicolumn{5}{|c|}{ Leaf potassium content, $\%$ DW } \\
\hline Control & $0.94 \pm 0.10$ & $0.70 \pm 0.06$ & $0.52 \pm 0.10$ & $0.72 \pm 0.09$ \\
\hline $\mathrm{N} 30 \mathrm{~K} 40$ & $1.04 \pm 0.18$ & $0.94 \pm 0.19^{*}$ & $0.72 \pm 0.15^{*}$ & $0.90 \pm 0.11^{*}$ \\
\hline $\mathrm{N} 60 \mathrm{~K} 80$ & $1.03 \pm 0.20$ & $0.82 \pm 0.28$ & $0.65 \pm 0.17$ & $0.83 \pm 0.14 *$ \\
\hline N90K120 & $1.03 \pm 0.08$ & $0.81 \pm 0.05$ & $0.67 \pm 0.12$ & $0.84 \pm 0.08^{*}$ \\
\hline N120K160 & $0.99 \pm 0.03$ & $0.78 \pm 0.06$ & $0.65 \pm 0.13$ & $0.81 \pm 0.08$ \\
\hline Average & $0.96 \pm 0.06$ & $0.81 \pm 0.07$ & $0.64 \pm 0.06$ & \\
\hline $\operatorname{LSD}_{05}$ & \multicolumn{3}{|c|}{$\begin{array}{c}\text { Year }=0.08 \\
\text { Treatments } \times \text { year }=0.17\end{array}$} & $\begin{array}{l}\text { Treatments } \\
0.10\end{array}$ \\
\hline \multicolumn{5}{|c|}{ Fruit potassium content, $\mathrm{mg} / 100 \mathrm{~g} \mathrm{FW}$} \\
\hline Control & $172.03 \pm 4.56$ & $189.35 \pm 5.70$ & $149.32 \pm 7.77$ & $170.23 \pm 8.46$ \\
\hline $\mathrm{N} 30 \mathrm{~K} 40$ & $175.76 \pm 10.50$ & $190.01 \pm 8.56$ & $167.95 \pm 10.98^{*}$ & $177.91 \pm 7.48$ \\
\hline N60K80 & $180.55 \pm 6.64$ & $181.87 \pm 15.05$ & $165.34 \pm 16.00^{*}$ & $175.92 \pm 8.14$ \\
\hline N90K120 & $193.01 \pm 11.91 *$ & $176.06 \pm 14.73$ & $173.33 \pm 9.21 *$ & $180.13 \pm 8.55^{*}$ \\
\hline N120K160 & $172.05 \pm 8.09$ & $178.78 \pm 8.30$ & $149.73 \pm 8.14$ & $166.85 \pm 7.53$ \\
\hline Average & $178.7 \pm 4.30$ & $182.8 \pm 5.13$ & $161.13 \pm 5.75$ & \\
\hline $\operatorname{LSD}_{05}$ & \multicolumn{3}{|c|}{$\begin{array}{c}\text { Year }=6.79 \\
\text { Treatments } \times \text { year }=15.18\end{array}$} & $\begin{array}{l}\text { Treatments } \\
8.76\end{array}$ \\
\hline
\end{tabular}

*differences with control are reliable at 5\% significance level

During the experiment, the potassium content in cherry leaves decreased annually. In 2019 , the decrease in the potassium status of the leaves can be explained by a twofold increase in the yield, as a result of which there was a redistribution of potassium between the leaves and fruits. In 2020, the average fruit yield did not differ significantly from the yield of 2019, and the decrease in the potassium concentration in the leaves can be explained by element leaching from plant tissues, which occurs as a result of prolonged heavy precipitation [19]. Other researchers also note a significant influence of weather conditions on the potassium content in cherry leaves [21].

The use of fertilizers annually improved the potassium status of the leaves, but the value of the indicator remained below the optimal limits (Table 3). Application of fertilizers in doses of N30K40, N60K80 and N90K120 contributed to an increase in potassium level by $0.11-0.18 \%$ DWon average for 3 growing seasons. The most stable effect was when the smallest dose of N30K40 was applied, where a significantly higher concentration of potassium in the leaves was observed in 2019 and 2020. When the maximum dose of N120K160 was applied, the effect was less pronounced.

It was found that the content of potassium in cherry fruits does not always depend on the fruit load [22]. In our experiment, the average experimental content of potassium in fruits in 2018 did not significantly differ from the level of 2019, although the harvest in 2018 was two times less. In 2020, under unfavorable weather conditions (heavy prolonged rains from May to July), the potassium status of fruits, as well as the potassium status of leaves, was significantly lower (on average by $22-29 \mathrm{mg} / 100 \mathrm{~g}$ ) than in previous years.

It is known that the positive effect of potassium fertilizers on plants is more pronounced in unfavorable weather conditions [23]. In the hydrothermal conditions of the growing 
season in 2020, potassium fertilizers had the greatest impact on the content of potassium in fruits. The values of the indicator were 1.12-1.16 times significantly higher than the control when applying N30K40, N60K80 and N90K120. When the largest dose of N120K160 was applied, the potassium content in the fruits was at the control level.

\section{Conclusion}

The study of the potassium regime of the cherry orchard in the soil and climatic conditions of the forest-steppe zone of the East European Plain showed that loamy Haplic Luvisol with reserves of exchangeable potassium of $156.0 \pm 12.2 \mathrm{mg} / \mathrm{kg}$ provides the potassium status of leaves within $0.52 \ldots 1.04 \% \mathrm{DW}$, which is below the optimal range for sour cherries.

The seasonal dynamics of exchange potassium forms in the upper soil layer depended on weather conditions and the uptake of the element by plants. A significant decrease in the indicator was observed during the period of intensive growth and crop formation, or after heavy precipitation. The use of potassium fertilizers significantly increased the content of exchangeable potassium in the soil (by 1.2-2.2 times), while the features of the element dynamics observed in unfertilized plots were preserved.

The use of fertilizers annually improved the potassium status of the leaves (by 0.05-0.24 $\% \mathrm{DW})$, but the indicator value remained below the optimal limits. The most significant decrease in the potassium content in cherry fruits and leaves was in the year with prolonged intense precipitation - 2020. In the same year, there was an increase in the content of potassium in fruits under the influence of fertilizers, as well of tree productivity. A significant increase of tree productivity was found when applying N60K80 and N120K160 (by 54 and $69 \%$, respectively).

\section{References}

1. FAOSTAT Crops. http://faostat.fao.org/beta/en/\#data/QC

2. M. Baghdadi, A. Sadowski, ActaHorticulturae. 468, 515-522 (1997) DOI: 10.17660/ActaHortic.1998.468.64

3. C. Shen, Li,Y., J. Wang, Y. Al Shoffe, C. Dong, Q. Shen, Y. Xu, Journal of Plant Growth Regulation. 37, 883-895 (2018) https://doi.org/10.1007/s00344-018-9783-1.

4. E. Szücs, International Journal of Horticultural Science. 9(2), 19-23(2003) https://doi.org/10.31421/IJHS/9/2/385

5. H. Yener, Ö. Altuntaş, Journal of Plant Nutrition. 44(7), 946-957 (2020) https://doi.org/10.1080/01904167.2020.1862203

6. S. Jiménez, A. Garín, Y. Gogorcena, JA. Betrán, M. A. Moreno, Journal of Plant nutrition. 27 (4), 701-712 (2004) https://doi.org/10.1081/PLN-120030376

7. K. Ucgun, Notulae Botanicae Horti Agrobotanici Cluj-Napoca. 47(1), 114-118(2019) https://dx.doi.org/10.15835/nbha47111225

8. K. Ucgun, M. Altindal, Communications in Soil Science and Plant Analysis. 52 (11), 1248-1255(2021) https://doi.org/10.1080/00103624.2021.1879122

9. A. Gomand, J. Vercammen, V. Siongers, D. Bylemans, Acta Horticulture. 1217, 239246 (2018) https://doi.org/10.17660/ActaHortic.2018.1217.30

10. A. Haberman, A. Dag, N. Shtern, I. Zipori, R. Erel, A. Ben-Gal, U. Yermiyahu, Agronomy. 9, 525 (2019) https://doi.org/10.3390/agronomy9090525

11. V.N. Yakimenko, Agricultural Chemistry. 10, 16-24 (2019) DOI:
10.1134/S0002188119100156 
12. A.I. Kuzin, N.Y. Kashirskaya, A.M. Kochkina, A.V. Kushner, Plants. 9(10), 1366 (2020) https://doi.org/10.3390/plants9101366

13. V.G.Mineev, V.G.Sychev, O.A.Amelyanchik, T.N.Bolsheva, N.F.Gomonova, E.P.Durynina, V.S.Egorov, E.V.Egorova, N.L. Edemskaya, E.A.Karpova, et al. Educational Aid on Agricultural Chemistry, 689 (Publishing House of Lomonosov Moscow State University: Moskow, Russia, 2001)

14. B.A. Dospekhov, A Field Experiment Method, 351 (1985)

15. A. Winkler, B. Fiedler, M. Knoche,Trees. 34, 1157-1167 (2020) https://doi.org/10.1007/s00468-020-01986-9

16. A.K. Kondakov, Fertilizing Fruit Trees, Berry-Fields, Nurseries and Flower Crops,327 (Michurinsk, Russia, 2007)

17. T.A. Roeva, E.V. Leonicheva, L.I. Leontieva, M. E. Stolyarov, The Bulletin of KrasGAU. 12 (165), 54-62 (2020) DOI: 10.36718/1819-4036-2020-12-54-62

18. G.M. Semenuk, Diagnostics of mineral nutrition of stone fruit crops with the use of information retrieval systems, 323(Kishinev, 1983)

19. V.G.Mineev, Agricultural Chemistry, 720 (Publishing House of Lomonosov Moscow State University: Moskow, Russia, 2004)

20. G.H. Neilsen, T. Edvards, Canadian Journal of Soil Science. 62 (2), 365-374 (1982) https://doi.org/10.4141/cjss82-040

21. K. Rutkowski, Z. Zydlik, A. Stachowiak, Folia Horticulturae. 30(1), 47-55 (2018) https://dx.doi.org/10.2478/fhort-2018-0005

22. G. Neilsen, F. Kappel, D. Neilsen, HortScience. 42(6), 1456-1462 (2007) https://doi.org/10.21273/HORTSCI.42.6.1456

23. V.N. Yakimenko, Agricultural Chemistry. 4, 3-12 (2015) 